\title{
Efektivitas pengomposan sampah organik menggunakan electrical rotary aerobic composter (ERAC)
}

\author{
Iswanto Iswanto ${ }^{a, c} \mathrm{I}^{*}$, Catur Puspawati ${ }^{\mathrm{b}, 2}$, Bambang Suwerda ${ }^{\mathrm{a}, 3}$ \\ a Jurusan Kesehatan Lingkungan, Poltekkes Kemenkes Yogyakarta, Jl Tata Bumi No 3 Sleman 55293 \\ b Jurusan Kesehatan Lingkungan, Poltekkes Kemenkes Jakarta II, Jl Hang Jebat III No 4 Jakarta Selatan 12120 \\ c PUI Novakesmas, Jl Tata Bumi No 3 Sleman 55293 \\ 1 iswanto.3r@gmail.com*; catpus06@yahoo.com; suwerda2006@yahoo.co.id \\ *korespondensi penulis
}

\begin{tabular}{l} 
Informasi artikel \\
\hline Sejarah artikel: \\
Diterima $\quad: 5$ Maret 202I \\
Revisi $\quad: 7$ Maret 202I \\
Dipublikasikan $\quad: 8$ Maret 202I \\
\hline Kata kunci: \\
ERAC \\
Sampah organic \\
Pengomposan \\
Kecepatan \\
Kualitas
\end{tabular}

\section{ABSTRAK}

Sampah organik yang dihasilkan di lingkungan Kampus I belum diolah dan hanya diangkut ke TPA Piyungan. Untuk mengatasi sampah organik diperlukan rekayasa teknologi yang dapat menghasilkan kompos secara cepat. Electrical Rotating Aerobic Composter (ERAC) adalah model komposter aerobik bertenaga listrik yang dirancang dapat berputar secara kontinyu sehingga dapat menjaga stabilitas faktor lingkungan (oksigen, suhu, kelembaban) dan homogenitas bahan organik yang diolah. Penelitian ini bertujuan untuk mengetahui pengaruh dan efektivitas kecepatan putaran alat ERAC terhadap waktu dan kualitas kompos berbahan sampah organik di lingkungan Kampus I Poltekkes Yogyakarta. Jenis penelitian ini adalah eksperimen dengan rancangan Post-Test Only with Control Group Design. Sampel penelitian berupa sampah organik kampus yang diambil secara proportionate stratified random sampling. Komposisi bahan yang diolah dengan ERAC terdiri atas: 1 bagian sampah organik dari kantin, 1 bagian sampah halaman/kebun, 1 bagian pupuk kandang dan $5 \%$ bioaktivator aktif yang dimasukkan ke dalam alat ERAC serta diatur kecepatan putarannya yaitu: $A=0,20 \mathrm{rpm}$; $\mathrm{B}=0,10 \mathrm{rpm}$; $\mathrm{C}=0,05$ $\mathrm{rpm} ; \mathrm{K}=0,00 \mathrm{rpm}$ (kontrol). Setiap perlakuan diulangi $3 \mathrm{kali}$ dan dipantau setiap hari sampai terbentuk kompos matang. Sampel kompos matang dikirim dan diperiksa kualitasnya di laboratorium. Berdasarkan parameter fisik (suhu, warna, tekstur dan bau) kompos, dapat diketahui bahwa ERAC mampu mengolah sampah organik kampus menjadi kompos dalam waktu 7 hari atau empat kali lebih cepat daripada kontrol (28 hari). Namun variasi kecepatan putaran tidak berpengaruh secara bermakna terhadap waktu pengomposan. Kualitas kompos yang dihasilkan telah memenuhi SNI Nomor 19-7030-2004 meliputi kadar air, N, P, K, C-organik dan C/N rasio Kualitas kompos menurut kecepatan putaran ERAC (0,20 rpm; 0,10 rpm; $0,05 \mathrm{rpm}$; kontrol $(0,00 \mathrm{rpm}))$ secara berurutan yaitu: $\mathrm{C} / \mathrm{N}$ ratio $(19,83$; $19,84 ; 19,95 ; 19,90)$; kadar air $(11,36 \% ; 10,81 \% ; 10,83 \% ; 10,97 \%)$; N (1,00\%; $1,06 \% ; 1,11 \% ; 1.024 \%)$; P (0,57\%;0,60\%; 0,58\%;0,64\%); K (1,37\%;1,32\%;1,30\%; 1,28\%); C-organik (19.69\%; 20,99\%; 21,90\%; 20,18\%).Hasil analisis statistik dengan uji Kruskal Wallis dengan Program SPPS versi 16 menunjukkan bahwa kadar air, N, P, C-organik dan C/N rasio antar tiga variasi kecepatan putaran ERAC tidak berbeda bermakna, kecuali kadar K. Namun bila dikaitkan dengan beban kerja mesin penggerak (engine) ERAC, maka kecepatan putaran yang paling rendah $(0,05 \mathrm{rpm})$ adalah yang paling efektif.

\begin{tabular}{ll}
\hline & ABSTRACT \\
\cline { 2 - 2 } Key word: & The effectiveness of composting organic waste using an electrical rotary \\
ERAC & aerobic composter (ERAC).Organic waste that produced in The Polytechnic \\
Organic waste & Health Yogyakarta campus has not been processed and just disposed to Piyungan \\
\hline
\end{tabular}


Composting

Quickness

Quality
Landfill. To recycle the organic waste is required engineering technology that can produce compost quickly. Electrical Rotating Aerobic Composter (ERAC) is an aerobic powered electric composter model that is designed to rotate continuously for maintaining the stability of environmental factors (oxygen, temperature, humidity) and the homogeneity of processed organic matter. This study aims to determine effect and effectiveness of rotation speed of the ERAC on duration and quality of compost. This research is an experiment with Post-Test Design Only with Control Group Design. The sample of this research is organic waste that taken by proportionate stratified random sampling in The Polytechnic Health Yogyakarta campus. The composition of organic materials filled in the ERAC consist of 1 part organic waste from the canteen, 1 part of the yard / garden waste, 1 part of cattle manure and $5 \%$ active bioactivator. Rotation speed of the ERAC was set with variations: $A=0.20 \mathrm{rpm} ; B=0.10 \mathrm{rpm} ; C=0.05 \mathrm{rpm} ; K=0.00 \mathrm{rpm}$ (control). Each treatment was repeated 3 times and monitored daily until compost was formed. Compost samples are sent and checked for quality in the laboratory. Based on the physical parameters (temperature, color, texture and smell) of compost, showed that ERAC is able to process organic waste into compost within 7 days or four times faster than control (28 days). However, the variation of rotation speed was not significantly affect duration of composting. The quality of compost that produced by ERAC has fulfilled SNI No. 19-7030-2004 including C/N ratio, water content, $N, P, K$ and C-organic. The compost quality according to rotation speed of the ERAC (0,20 rpm; 0,10 rpm; 0, $05 \mathrm{rpm}$, control (0.00 rpm)) respectively are: C / $N$ ratio $(19,83,19,84,19,95,19,90)$; water content $(11,36 \% ; 10,81 \%$; $10,83 \% ; 10,97 \%) ; N(1.00 \% ; 1.06 \% ; 1.11 \% ; 1,024 \%) ; P(0,57 \% ; 0,60 \% ; 0,58 \%$; $0,64 \%)$; K (1.37\%; 1.32\%; $1.30 \% ; 1.28 \%)$; C-organic $(19.69 \% ; 20,99 \% ; 21,90 \%$; $20,18 \%)$.The result of statistical analysis with Kruskal Wallis test with SPPS program version 16 showed that water content, $N, P, C$-organic and C / N ratio between the three variations of rotation speed of ERAC is not significantly different, except $K$ level. But when it was associated with workload of the ERAC engine, the lowest rotation speed $(0.05 \mathrm{rpm})$ is the most effective.

This is an openaccess article under the CC-BY-SA license.

\section{Pendahuluan}

Salah satu rencana strategis Politeknik Kesehatan Kemenkes Yogyakarta Tahun 2015 2019 adalah mewujudkan kampus berwawasan lingkungan (Green Campus) dengan melakukan pengurangan sampah melalui penerapan 3R (Reduce, Reuse, Recycle) dan penanganan sampah melalui kegiatan pemilahan dan pengolahan. Semua sampah organik yang dihasilkan belum diolah dan hanya dikumpul kemudian diangkut ke TPA Piyungan.

Pembusukan sampah organik secara anaerobik menghasilkan gas yang berbau seperti amoniak dan asam-asam volatil lainnya serta menghasilkan gas metan yang dapat menimbulkan pemanasan global serta membahayakan keselamatan dan kesehatan bagi masyarakat. Sampah organik menjadi tempat mencari makan dan berkembangbiaknya vektor penyakit dan binatang pengganggu seperti lalat, kecoa dan tikus. Sampah organik berpotensi menjadi media penularan berbagai penyakit saluran intestinal seperti diare, disentri dan tifus, sehingga penumpukan sampah organik dalam waktu yang lama harus dihindari. Oleh karena itu, pengolahan sampah organik perlu dilakukan dengan cepat. 
Pengomposan merupakan proses penguraian sampah organik secara biologi pada kondisi udara yang terkendali menjadi suatu bentuk yang stabil dan tidak mengganggu baik dalam penyimpanan maupun penanganannya serta hasilnya aman digunakan untuk pertanian. ${ }^{[1]}$ Selain organisme hidup, ada tiga faktor yang mempengaruhi kecepatan pengomposan yaitu: nutrisi, lingkungan dan operasional. Apabila sampah organik mengandung nutrisi yang sesuai dengan kebutuhan organisme pengurai maka pengomposan akan berjalan lebih cepat. ${ }^{[1]}$

Faktor lingkungan yang menentukan kecepatan pengomposan adalah kelembaban, suhu dan oksigen. Kelembaban yang perlu diciptakan agar organisme tetap hidup optimal adalah antara $50-60 \%$. Kelembaban di bawah $12 \%$ dapat mengakibatkan organisme pengurai tidak aktif. Suhu dalam pengomposan diupayakan agar tidak lebih dari $60^{\circ} \mathrm{C}$ sehingga organisme mesofilik dapat bertahan hidup. $[1],[2],[3],[4]$

\section{Metode}

Jenis penelitian ini adalah eksperimen dengan rancangan Post-Test Only with Control Group Design. Sampel penelitian berupa sampah organik yang dihasilkan di lingkungan Kampus I Poltekkes Yogyakarta. Komposisi bahan yang diolah dengan ERAC: 1 bagian sampah organik dari kantin, 1 bagian sampah halaman/ kebun, 1 bagian kompos matang dan 5\% bioaktivator aktif yang dimasukkan ke dalam komposter ERAC dan diatur kecepatan putarannya dengan variasi: A (0,20rpm); B (0,10rpm); C (0,05 rpm); K (kontrol=0,00 rpm) dengan 3 kali pengulangan. Sampel kompos matang diperiksa kualitasnya di laboratorium dan dibandingkan dengan SNI Nomor 19-7030-2004 tentang Spesifikasi Kompos dari Sampah Organik Domestik

\section{Hasil dan Pembahasan}

\section{Pengaruh Kecepatan Putaran ERAC terhadap Waktu Pengomposan}

Hasil pengukuran terhadap timbulan sampah organik yang dihasilkan di Kampus I Poltekkes Yogyakarta selama 8 (delapan) hari kerja diketahui rata-rata sebesar 62,56 liter/hari kerja, terdiri atas sampah halaman (52,5 liter/hari) dan sampah kantin (10,06 liter/hari).

Tabel 1.

Pengaruh Kecepatan Putaran ERAC terhadap Lama Pengomposan

\begin{tabular}{llllll}
\hline $\begin{array}{l}\text { Perlakuan } \\
\text { (rpm) }\end{array}$ & \multicolumn{2}{l}{$\begin{array}{l}\text { waktu pengomposan (hari) berdasarkan } \\
\text { indikator fisik }\end{array}$} & $\begin{array}{l}\text { Kesimpulan lama } \\
\text { komposting }\end{array}$ \\
\cline { 2 - 5 } & bau & tekstur & warna & suhu & \\
\hline A $(0,20)$ & 6 & 6 & 5 & 7 & 7 hari \\
B $(0,10)$ & 6 & 6 & 5 & 7 & 7 hari \\
C $(0,05)$ & 6 & 6 & 5 & 7 & 7 hari \\
K(kontrol) & 14 & 21 & 14 & 28 & 28 hari \\
\hline
\end{tabular}


Berdasarkan indikator fisik (suhu, warna, tekstur dan bau) menunjukkan bahwa secara keseluruhan penggunaan komposter ERAC dapat mempercepat proses pengomposan empat kali dibandingkan kontrol, yaitu dari 28 hari menjadi 7 hari. Tabel 1 juga memperlihatkan bahwa kecepatan putaran ERAC tidak berbeda antara 0,20 rpm, 0,10 rpm dan 0,05 rpm yaitu sama-sama 7 (tujuh) hari.

Pengomposan dengan alat ERAC secara nyata dapat mempercepat proses pengomposan Rata-rata waktu pengomposan pada semua kecepatan putaran baik 0,20 rpm, 0,10 rpm maupun 0,10 rpm adalah sama yaitu 7 (tujuh) hari atau lebih cepat 4 kalinya dibandingkan dengan kontrol (tanpa pemutaran) yang memerlukan waktu pengomposan 28 hari. Pengadukan sampah melalui putaran ERAC secara kontinyu dapat menjaga homogenitas campuran secara terus menerus sehingga dapat menciptakan lingkungan yang kondusif bagi kehidupan organisme pengurai. Semakin banyak mikroba pengurai yang hidup dan aktif akan mempercepat pengomposan. Proses penguraian bahan organik menjadi kompos memerlukan kondisi tertentu meliputi kecukupan oksigen, suhu dan kelembaban. Semakin sesuai kondisinya, semakin cepat terbentuknya kompos. ${ }^{[2] \cdot[3]}$

Oksigen merupakan komponen utama yang diperlukan bagi kehidupan mikroorganisme aerobik. ${ }^{[9],[10],[11]}$ Bahan organik akan mengalami dekomposisi dengan cepat jika berada dalam keadaan aerob. Mikroorganisme aerob mengonsumsi banyak oksigen selama proses dekomposisi materi organik. Bahan-bahan yang mudah terurai akan dimetabolisme secara cepat selama pengomposan.

Putaran alat ERAC berfungsi untuk pembalikan bahan organik secara terus menerus. Pembalikan dapat memburaikan bahan-bahan pengomposan dan dapat mencegah kepadatan bahan organik sehingga tercipta rongga-rongga udara di antara partikel-partikel bahan yang dikomposkan. Alat ERAC dilengkapi dengan lubang ventilasi pada bagian samping kanan dan kiri. Ventilasi tersebut menjadi lubang pertukaran udara, yaitu sebagai jalan masuk oksigen dari luar dan jalan keluar dari gas-gas hasil dekomposisi secara aerobik misalnya $\mathrm{CO}_{2}$.

Kelembaban bahan organik yang ada di dalam alat ERAC dapat merata pada seluruh bagian karena dilakukan pengadukan (pemutaran) secara terus menerus. Kelembaban yang merata berdampak pada menyebarnya mikroba secara merata pula sehingga semua bagian dari bahan organik tersedia mikroba. Hal tersebut yang mengakibatkan proses pengomposan menggunakan ERAC lebih cepat dibandingkan yang tidak dilakukan pembalikan (kontrol). Kelembaban pada kontrol tidak merata, bahan organik pada lapisan atas nampak kering (kelembaban rendah), sedangkan lapisan bagian bawah terlihat sangat basah (kelembaban tinggi). Kondisi ini yang menyebabkan waktu pengomposan pada kelompok kontrol lebih lama dibandingkan kelompok perlakuan.

Selain itu, melalui lubang ventilasi yang ada di samping kanan-kiri alat ERAC, dapat juga mengeluarkan kalor atau panas yang muncul pada saat proses pengomposan, sehingga suhunya lebih stabil dan tidak terlalu tinggi. Akibatnya akan tercipta lingkungan yang kondusif bagi kehidupan mikroba pengurai.

\section{Pengaruh Kecepatan Putaran ERAC terhadap Kualitas Kompos}

\section{Kandungan karbon (C-organik)}

Hasil pemeriksaan kadar C di dalam kompos yang telah matang tersaji pada Tabel 2. 
Tabel 2. Perbandingan Kandungan Karbon (C-organik)

\begin{tabular}{ccccc}
\hline \multirow{2}{*}{ Ulangan } & \multicolumn{4}{c}{ Kandungan C-organik (\%) } \\
\cline { 2 - 5 } & $\mathrm{K}$ & $\mathrm{A}$ & $\mathrm{B}$ & $\mathrm{C}$ \\
\hline 1 & 18.672 & 19.933 & 20.224 & 22.224 \\
2 & 19.892 & 19.069 & 21.073 & 20.588 \\
3 & 21.967 & 20.069 & 21.685 & 22.889 \\
\hline Rerata & 20.177 & 19.690 & 20.994 & 21.900 \\
\hline
\end{tabular}

Tabel 2 menunjukkan bahwa kadar C-organik di dalam kompos telah memenuhi SNI yaitu antara 9,8-32\%. Nilai Asymp. sig dari uji Kruskal Wallis dengan SPSS versi 16 sebesar 0,123 . Artinya kadar air untuk semua perlakuan termasuk kontrol tidak berbeda secara bermakna, sehingga variasi kecepatan putaran mesin ERAC tidak berpengaruh secara bermakna terhadap C-organik.

\section{Kandungan Nitrogen (N)}

Perbandingan kadar nitrogen $(\mathrm{N})$ di dalam kompos terlihat pada Tabel 3.

Tabel 3.Perbandingan Kandungan Nitrogen (N)

\begin{tabular}{ccccc}
\hline \multirow{2}{*}{ Ulangan } & \multicolumn{4}{c}{ Kandungan Nitrogen $(\%)$} \\
\cline { 2 - 5 } & $\mathrm{K}$ & $\mathrm{A}$ & $\mathrm{B}$ & $\mathrm{C}$ \\
\hline 1 & 0.961 & 1.125 & 1.087 & 1.018 \\
2 & 1.165 & 0.918 & 0.987 & 1.248 \\
3 & 0.947 & 0.956 & 1.108 & 1.064 \\
\hline Rerata & 1.204 & 1.000 & 1.061 & 1.110 \\
\hline
\end{tabular}

Tabel 3 menunjukkan bahwa kadar $\mathrm{N}$ di dalam kompos telah memenuhi SNI yaitu $\geq$ 0,40\%. Nilai Asymp. sig dari uji Kruskal Wallis dengan SPSS versi 16 sebesar 0,599. Artinya kadar $\mathrm{N}$ untuk semua perlakuan termasuk kontrol tidak berbeda secara bermakna, sehingga variasi kecepatan putaran mesin ERAC tidak berpengaruh secara bermakna terhadap kandungan nitrogen.

\section{Kandungan Fosfor (P)}

Perbandingan kadar fosfor $(\mathrm{P})$ di dalam kompos terlihat pada Tabel 4.

Tabel 4. Perbandingan Kandungan Fosfor (P)

\begin{tabular}{ccccc}
\hline \multirow{2}{*}{ Ulangan } & \multicolumn{4}{c}{ Kandungan Fosfor $(\%)$} \\
\cline { 2 - 5 } & $\mathrm{K}$ & $\mathrm{A}$ & $\mathrm{B}$ & $\mathrm{C}$ \\
\hline 1 & 0.661 & 0.571 & 0.604 & 0.573 \\
2 & 0.629 & 0.583 & 0.621 & 0.565 \\
3 & 0.623 & 0.593 & 0.567 & 0.562 \\
\hline Rerata & 0.638 & 0.582 & 0.597 & 0.567 \\
\hline
\end{tabular}


Tabel 3 menunjukkan bahwa kadar P di dalam kompos telah memenuhi SNI yaitu $\geq$ 0,10\%. Nilai Asymp. sig dari uji Kruskal Wallis dengan SPSS versi 16 sebesar 0,066. Artinya kadar P untuk semua perlakuan termasuk kontrol tidak berbeda secara bermakna, sehingga variasi kecepatan putaran mesin ERAC tidak berpengaruh secara bermakna terhadap kandungan fosfor.

\section{Kandungan Kalium (K)}

Perbandingan kadar kalium (K) di dalam kompos terlihat pada Tabel 5.

Tabel 5.

Perbandingan Kandungan Kalium (K)

\begin{tabular}{ccccc}
\hline \multirow{2}{*}{ Ulangan } & \multicolumn{4}{c}{ Kandungan Kalium (\%) } \\
\cline { 2 - 5 } & $\mathrm{K}$ & $\mathrm{A}$ & $\mathrm{B}$ & $\mathrm{C}$ \\
\hline 1 & 1.27 & 1.29 & 1.32 & 1.36 \\
2 & 1.28 & 1.3 & 1.32 & 1.38 \\
\hline 3 & 1.28 & 1.3 & 1.33 & 1.367 \\
\hline
\end{tabular}

Tabel 5 menunjukkan bahwa kadar K di dalam kompos telah memenuhi SNI yaitu $\geq 0,20 \%$. Nilai Asymp. sig dari uji Kruskal Wallis dengan SPSS versi 16 sebesar 0,015, berarti ada pengaruh bermakna variasi kecepatan putaran mesin ERAC terhadap kandungan kalium di dalam kompos.

\section{Nilai $\mathrm{C} / \mathrm{N}$ ratio}

Perbandingan $\mathrm{C} / \mathrm{N}$ ratio di dalam kompos terlihat pada Tabel 6.

Tabel 6.

Perbandingan C/N Ratio

\begin{tabular}{ccccc}
\hline \multirow{2}{*}{ Ulangan } & \multicolumn{4}{c}{ Kandungan C/N } \\
\cline { 2 - 5 } & $\mathrm{K}$ & $\mathrm{A}$ & $\mathrm{B}$ & $\mathrm{C}$ \\
\hline 1 & 19.43 & 17.718 & 18.605 & 21.831 \\
2 & 17.075 & 20.772 & 21.351 & 16.497 \\
3 & 23.196 & 20.993 & 19.571 & 21.512 \\
\hline Rerata & 19.900 & 19.828 & 19.842 & 19.947 \\
\hline
\end{tabular}

Tabel 6 menunjukkan bahwa C/N ratio di dalam kompos telah memenuhi SNI yaitu (10-20) : 1. Nilai Asymp. sig dari uji Kruskal Wallis dengan SPSS versi 16 sebesar 0,972. Artinya variasi kecepatan putaran mesin ERAC tidak berpengaruh secara bermakna terhadap $\mathrm{C} / \mathrm{N}$ ratio di dalam kompos.

\section{Kuantitas kompos yang dihasilkan}

Setelah proses pengomposan bahan-bahan organik (sampah) mengalami penyusutan volume dari bahan baku (150 liter) menjadi kompos sebagaimana tersaji pada Tabel 7. 
Pengomposan dengan ERAC dapat menurunkan kuantitas bahan organik (sampah) rata-rata $62,86 \%$. Berat kompos yang dihasilkan setiap pengolahan dengan alat ERAC rata-rata seberat $=(0,81 \mathrm{~kg} /$ liter $) \times 94,29$ liter $=76,37 \mathrm{~kg}$

Tabel 7

Kuantitas Kompos dan Penyusutan Bahan Organik

\begin{tabular}{lcccc}
\hline \multirow{2}{*}{ Ulangan } & \multicolumn{4}{c}{$\begin{array}{c}\text { Kuantitas Kompos dan Penyusutan } \\
\text { Bahan Organik (liter) }\end{array}$} \\
\cline { 2 - 4 } & Kontrol & $\mathrm{A}$ & $\mathrm{B}$ & $\mathrm{C}$ \\
\hline Ulangan I & 96,60 & 88,20 & 91,80 & 94,00 \\
Ulangan II & 94,40 & 95,40 & 97,40 & 95,60 \\
Ulangan III & 93,80 & 96,60 & 92,40 & 97,20 \\
Jumlah & 284,80 & 280,20 & 281,60 & 286,8 \\
\hline Rata-rata & 94,93 & 93,40 & 93,870 & 95,60 \\
\hline Penyusutan & $63,29 \%$ & $62,27 \%$ & $62,58 \%$ & $63,73 \%$
\end{tabular}

Kualitas kompos ditentukan berdasarkan karakteristik fisik, kimia dan biologi. Di dalam penelitian ini, kualitas kompos terbatas dilihat dari kualtias fisik dan kimia. Hasil pemeriksaaan terhadap kualitas kompos menunjukkan bahwa kompos yang dihasilkan pengolahan sampah organik dari Kampus I Poltekkes Kemenkes Yogyakarta dengan menggunakan rekayasa alat ERAC telah memenuhi karakteristik fisik dan kimia (unsur hara makro) sebagaimana yang dipersyaratkan di dalam SNI nomor 19-7030-2004 tentang spesifikasi kompos dari sampah organik domestik.

SNI nomor 19-7030-2004 merupakan Standar Nasional Indonesia yang mengatur produk kompos guna melindungi konsumen dan mencegah terjadinya pencemaran lingkungan. Di dalam SNI nomor 19-7030-2004 disebutkan bahwa kompos matang harus memenuhi beberapa indikator utama yaitu: suhu sesuai dengan suhu air tanah $\left(<30^{\circ} \mathrm{C}\right)$, bewarna kehitaman dan tekstur seperti tanah, berbau tanah serta memiliki nilai $\mathrm{C} / \mathrm{N}$ ratio sebesar (10 - 20):1.

Suhu kompos yang masih terasa hangat atau melebihi suhu udara lingkungan sekitar mengindikasikan bahwa mikroba pengurai masih beraktivitas melakukan proses dekomposisi sehingga menghasilkan panas di dalam tumpukan bahan organik. Apabila tidak ada pengadukan, maka kalor yang ada di dalam bahan kompos sulit keluar sehingga semakin mengakibatkan suhu kompos awet hangat. Proses pengadukan rutin dan didukung adanya aerasi di dalam ERAC dapat menyebabkan kalor terlepas keluar sehingga suhu kompos di dalam alat lebih cepat mendekati suhu lingkungan. Suhu di dalam kompos ada kaitannya dengan C/N ratio. Hasil penelitian Yuniwati, dkk (2011) menunjukkan bahwa suhu yang tinggi di dalam bahan yang dikomposkan cenderung memiliki $\mathrm{C} / \mathrm{N}$ ratio yang tinggi pula. Sebaliknya suhu yang semakin menurun memperlihatkan $\mathrm{C} / \mathrm{N}$ ratio yang semakin rendah. ${ }^{[7]}$

Nilai $\mathrm{C} / \mathrm{N}$ ratio tanah umumnya di bawah 20:1. Oleh karenanya kompos yang sudah matang juga harus menyesuaikan $\mathrm{C} / \mathrm{N}$ ratio tanah tersebut yaitu di bawah 20:1. Komposter ERAC mampu menurunkan C/N ratio pada bahan baku yaitu dari 24:1 menjadi di bawah 20:1. Kompos matang merupakan bahan suplemen yang mengandung nutrisi bagi tumbuhtumbuhan. Apabila sudah ada kesesuaian $\mathrm{C} / \mathrm{N}$ ratio antara kompos dan tanah, maka unsurunsur hara yang terkandung di dalam kompos dapat langsung diserap oleh akar tanaman. 
Penggunaan kompos yang belum matang pada media tanaman atau tanah dapat mematikan tumbuh-tumbuhan karena $\mathrm{C} / \mathrm{N}$ ratio yang tidak sesuai. ${ }^{[4]}$

Kualitas produk akhir kompos utamanya ditentukan oleh karakteristik dan komposisi bahan baku (raw material) yaitu sampah organik dan campurannya. ${ }^{[17]}$ Jenis dan komposisi sampah organik beserta campuran bahan lain di dalam penelitian ini dikondisikan sama. Walaupun diproses dengan variasi kecepatan putaran yang berbeda $(0,20 \mathrm{rpm} ; 0,10 \mathrm{rpm} ; 0,05$ rpm) bahkan tanpa putaran sekalipun (kontrol/0,00 rpm), ternyata kualitas kompos yang dihasilkan menunjukkan tidak ada perbedaan yang bermakna. Kualitas kompos yang diukur dari alat ERAC ini meliputi kandungan karbon $(\mathrm{C})$, nitrogen $(\mathrm{N})$, phosphor $(\mathrm{P})$ dan kalium $(\mathrm{K})$. Kandungan semua unsur hara makro tersebut telah memenuhi spesifikasi kompos yang ditetapkan yaitu SNI nomor 19-7030-2004 tentang spesifikasi kompos dari sampah organik domestik. ${ }^{[5]}$

Meskipun tidak ada pengaruh variasi kecepatan putaran ERAC terhadap waktu pengomposan, tetapi komposter ERAC mampu mengolah sampah organik lebih cepat dibandingkan tanpa putaran. Selain itu pula variasi kecepatan putaran ERAC tidak berpengaruh secara bermakna terhadap kualitas kompos yang dihasilkan. Artinya variasi kecepatan putaran ERAC yaitu 0,20 rpm; 0,10 rpm; 0,05 rpm memiliki efektivitas yang sama terhadap waktu pengomposan dan kualitas kompos.

Untuk menentukan kecepatan putaran alat ERAC yang paling efektif perlu mempertimbangkan aspek lain, yaitu konsumsi listrik dan beban kerja mesin penggerak (engine) pada ERAC. Alat ERAC memerlukan satu unit mesin penggerak bertenaga listrik berkekuatan 0,5 HP atau setara dengan 390 watt. Berdasarkan tarif listrik untuk pelayanan publik pada bulan Oktober 2017 untuk wilayah DIY sebesar Rp 1.076/kWh. Biaya yang harus dikeluarkan untuk setiap kali perlakuan $=(390$ watt/1000 $) \times 24$ jam $\times 7$ hari $\times$ Rp. $1076=\mathrm{Rp}$ $70.499,52 \approx \operatorname{Rp} 70.500,00$. Kecepatan putaran ERAC tidak berpengaruh terhadap besarnya konsumsi listrik, sehingga tidak dapat dipakai sebagai dasar untuk memilih yang paling efektif.

Beban kerja mesin penggerak ERAC dipengaruhi oleh kecepatan putaran. Semakin cepat putaran, semakin berat beban kerja dari mesin penggerak (dinamo). Semakin berat beban kerjanya, semakin cepat resiko kerusakannya. Berdasarkan kajian dari berbagai aspek tersebut, maka kecepatan yang paling lambat yaitu 0,05 rpm adalah yang paling efektif dalam pengomposan menggunakan alat ERAC.

Jumlah kompos yang dihasilkan mengalami penyusutan volume dari bahan bakunya (150 liter) yaitu sebesar 62,86\%, sehingga kompos yang dihasilkan rata-rata $=94,29$ liter atau $76,37 \mathrm{~kg}$ per alat ERAC. Agar dapat mengolah sampah organik yang dihasilkan di Kampus I Poltekkes Yogyakarta yaitu rata-rata $=312,6$ liter per minggu, maka kapasitas komposter ERAC yang perlu disiapkan adalah 312,6 liter $+(25 \% \times 312,6$ liter $)=390,76$ liter $\approx 400$ liter, sehingga jumlah kompos yang akan dihasilkan selama 1 tahun sebanyak (312,6 liter $\mathrm{x} 4$ kali $\mathrm{x}$ 12 bulan) $\times 62,86 \%=15.004,8$ liter $=12.153,89 \mathrm{~kg}$ atau sekitar 12,15 ton/tahun .

\section{Kesimpulan}

Komposter model ERAC dapat mempercepat proses pengomposan dari 28 hari (kontrol) menjadi 7 hari. Kecepatan putaran ERAC tidak berpengaruh secara bermakna 
terhadap waktu pengomposan. Kecepatan putaran ERAC juga tidak berpengaruh secara bermakna terhadap kualitas kompos yang dihasilkan. Kualitas kompos yang dihasilkan dari ERAC telah memenuhi standar kadar air, C-organik, N, P, K dan C/N ratio sesuai SNI no. 197030-2004. Kecepatan putaran ERAC yang paling efektif untuk mengolah sampah organik di lingkungan Kampus I Poltekkes Kemenkes Yogyakarta adalah 0,05 rpm.

\section{Daftar Pustaka}

1. Anonim, 2005, Solid Waste Management, United Nations Environmental Program, Calrecovery.

2. Christianto, 2005, Pengomposan Sampah Rumah Tangga, Surabaya: PUSDAKOTA UBAYA - JFGE - KITA

3. Suryohadikusumo, D. dan Murniyati, S., 2009. Mengolah Sampah Menjadi Berkah dalam Pengabdian Tiada Henti, Jakarta: Yayasan Sandana Asih

4. Anonim, 2000, Composting, Texas: Environmental Engineering National Engineering Handbook.

5. SNI nomor 19-7030-2004 tentang spesifikasi kompos dari sampah organik domestik

6. Djuarnani. 2005. Pengaruh Ukuran Partikel terhadap Kualitas Kompos. Jakarta Selatan: Jurnal Ilmi-Ilmu Pertanian Indonesia. Agromedia Pustaka.

7. Yuniwati, M., Iskarima, F., dan Padulemba, A., 2011. Optimasi Kondisi Pembuatan Kompos dari Sampah Organik dengan Cara Fermentasi Menggunakan EM4. Journal Teknologi, Volume 5 No. 2: 172 - 181.

8. Alex S, 2011, Sukses Mengolah Sampah Organik Menjadi Pupuk Organik, Yogyakarta: Pustaka Baru Press.

9. Holmer, L.J., 2002, Basic Composting for Composting of Biodegradable Household Wastes, Chagayan de Oro City, Philiphine: Xavier University College of Agriculture

10. Gounot, A.M. 1991. Bacterial life at low temperature:physiological aspects and biotechnological implications. Journal of Applied Bacteriology (7): 386-397

11. Holt, J.G., Kreig,N.R., Sneath, P.H.A., Staley, JT., and Williams ST, 1994. Bergey's Manual of Determinantive Bacteriology $9^{\text {th }}$ ed. Lippincott Williams \$ Wilkins, USA: $597-603$.

12. Muktiningsih, S.D., Wirosoedarmo, R., Haji, A.T.S., Anugroho, F., Sulianto, A.A., dan Lusiana N., 2016. Evaluasi Teknis Pengomposan Sampah Daun di UPT Kompos Universitas Brawijaya. Jurnal Teknologi Pertanian Vol. 17 No. 3: 165-176.

13. Widarti, B.N., Wardhini, W.K., Sarwono, E. 2015. Pengaruh rasio C/N bahan baku pada pembuatan kompos dari kubis dan kulit pisang. Jurnal Integrasi Proses 5(2): 75-80. 